\section{George Deacon and the circulation of homeopathic therapies in Lima (1880-1915)}

\section{George Deacon e a circulação de tratamentos homeopáticos em Lima (1880-1915)}

\author{
Patricia Palma ${ }^{i}$ \\ ' Researcher, Departamento de Ciencias Históricas y Geográficas/ \\ Universidad de Tarapacá. \\ Arica - Región de Arica y Parinacota - Chile \\ orcid.org/0000-0003-1328-9635 \\ ppalma@uta.cl
}

PALMA, Patricia. George Deacon and the circulation of homeopathic therapies in Lima (1880-1915). História, Ciências, Saúde - Manguinhos, Rio de Janeiro, v.26, n.4, out.-dez. 2019, p.1263-1280.

\section{Abstract}

Homeopathy arrived from the United States to Peruvian soil in the last decades of the nineteenth century, broadening the repertoire of existing medical knowledge, which included an emerging medical profession, Chinese herbalists, and indigenous practitioners. This article examines the circulation and use of homeopathic therapies and medicines in Lima from the time when the American homeopath George Deacon initiated his practice, in the 1880s, until his death, in 1915. Although homeopathy was not the most widely used medical therapy in the country, it nevertheless posed a threat to professional medicine and the School of Medicine's desired monopoly of the field of medicine.

Keywords: Peru; homeopathy; George Deacon (1853-1915); medical pluralism; medical profession.

Resumo

A homeopatia originária dos EUA adentrou solo peruano nas últimas décadas do século XIX, ampliando o repertório de conhecimento médico existente até então, o qual incluía uma profissão médica em ascensão, herbolários chineses e médicos locais. Este artigo analisa a circulação e o uso de tratamentos e medicamentos homeopáticos em Lima desde o período em que o homeopata norte-americano George Deacon iniciou sua prática, nos anos 1880, até sua morte, em 1915. Embora a homeopatia não fosse o tratamento médico mais disseminada no país, ela representou uma ameaça à medicina profissional e ao monopólio do campo da medicina almejado pela escola tradicional.

Palavras-chave: Peru; homeopatia; George Deacon (1853-1915); pluralismo médico; profissão médica. 
$I^{\prime}$ February 1896, the Medical Journal, the American journal of homeopathic medicine and surgery, published an enthusiastic letter from a former student of Pulte Medical College in Ohio announcing a new triumph for the global practice of homeopathy. George Deacon M.D., an American homeopath who settled in Peru in the 1880s, reported that after a long battle with local physicians, the Peruvian Congress had allowed homeopaths to practice medicine in the country without supervision from the School of Medicine of Lima (Facultad de Medicina de Lima). "It has been a labor of many years, as you know, a struggle of one man against a hundred," wrote doctor Deacon (1896, p.70). This triumph of an obscure David against the mighty Goliath was the result of almost ten years of legal battles between Deacon and doctors from the School of Medicine of Lima, during which professional doctors sought to discredit homeopathy and its practitioners. The ruling threatened the School of Medicine's attempts to monopolize medical practice and resulted in a conflict between it and Congress in which it claimed that legislators had undermined its authority.

By the time readers learned about this strange victory in a distant country of South America, homeopathy was one of a vast repertoire of medical therapies, which included an emerging medical profession, Chinese herbalists, and indigenous practitioners. While doctors from the School of Medicine rejected this methodology and remained hostile to homeopaths like doctor Deacon, the country's elites deemed the therapy a triumph of modernity and began to use its products. Lima's educated, well-traveled ruling classes knew that "civilized countries" hosted many practitioners and even schools of homeopathic medicine and hoped that Peru would follow suit. For them, homeopaths were the symbol of progress and modernization that Peru required.

This article examines the circulation and use of homeopathic therapies and medicines in Lima following the professional trajectory of George Deacon from the beginnings of his medical practice in the 1880s until his death, in 1915. I demonstrate that despite the limited number of homeopaths practicing in the country, this healing system held a central role in the medicinal marketplace, a consumer space where patients could choose from a diversity of medical practitioners and products (Jenner, Wallis, 2007). Because of intense trade between the United States and Peru, patients and practitioners could acquire, use, and recommend homeopathic treatments. In the public arena, George Deacon undermined the position of the School of Medicine of Lima and professional medicine in the country. A decade of debates about the status of homeopathy deepened the conflicts amongst various actors in society who had conflicting perspectives on public health and the role homeopathy should play in it.

This article is divided in three parts. Part one analyzes the trajectory of George Deacon, responsible for introducing the discussion of the rights of homeopathic physicians to the public sphere in Peru. More importantly, he was the only alternative medical practitioner that took part in the debate about the relevance of medical pluralism and the need to break the suffocating monopoly of the School of Medicine in the Peruvian Congress. The second part takes a close look at the debates between supporters and detractors of homeopathy in the Peruvian Congress during the 1880s and 1890s. I explore how doctors from the School of Medicine of Lima defined homeopathy and show why they sought to deny homeopaths 
the right to hold professional titles. To the Dean of the School of Medicine and professional doctors, both homeopaths and Congress had infringed upon their domain: that of public medicine. Finally, I explore the circulation of homeopathic kits and medicines in the late nineteenth century. Every year, hundreds of homeopathic kits and manuals were imported from the United States, enabling people to treat family and community members in an informal practice following the guidelines of American homeopaths. To trace these stories, I analyze the introduction of such products into local markets, and the publicity that fostered their consumption. ${ }^{1}$

\section{George Deacon and the "struggle of one man against a hundred"}

At the end of eighteenth century, the German physician Samuel Hahnemann (1755-1843) developed a field of experimental pharmacology, stating the principle of similia similibus curantur, or "like cures like," meaning that diseases could be cured by the administration of remedies that produced effects similar to those of the disease. Following this "law of similars," he called his healing system "homeopathy," from the Greek for "like" and "suffering," while referring to institutional Western medicine as "allopathy," from the Greek for "unlike" and suffering" (Whorton, 2004). Hahnemann investigated the effects of various potential drugs to determinate what symptoms they would cure. By 1800, he had developed the "law of infinitesimals," which argued that the smaller the dose, the more it stimulated the body's vital force. Within a few years, these principles had circulated to a different part of the world, finding particular acceptance in the United States (Kaufman, 1988; Whorton, 2004; Janik, 2014; Coulter, 1982).

In Latin America, the use of homeopathy dates back to the Wars of Independence. In 1817, the revolutionary general José de San Martín, who suffered the pains of osteoarthritis and ulcers, crossed the Andes carrying his own homeopathic kit that a friend of his had brought from Europe (Vijnovsky, 2008, p.45-47). It took only a few years for homeopathy to become a component of a medically plural health care system in several countries of Latin America. In 1850, the Spanish homeopath doctor Benito García Fernández arrived in Chile from Cuba, introducing the practice in the country and attracting the attention of important figures, among them the former president Francisco Antonio Pinto (18271829), who embraced the new therapeutic system (Briones, 2010). Around the same time, thousands of miles away, another Spanish homeopath named doctor Ramón Cormellas began his practice in Mexico. Within a few decades, homeopathy had gained the support of important members of the Mexican elite and government, such as the presidents Porfirio Díaz and Francisco Madero (Hernández, 2017; Carrillo, 2010).

Unlike the rest of Latin America, the origins of homeopathy in Peru are still unclear, in part because scholars of the history of medicine have paid little attention to noninstitutional and non-Western forms of medical therapies. In one of the few studies devoted to the history of homeopathy around the world, Eswara Das states that the first person to apply homeopathy in Peru was an English immigrant named Henry Whittwell, who arrived in the north-western coast town of Trujillo in 1910 (Das, 2005, p.206). However, other historical records suggest that a German doctor may have introduced this healing 
therapy popularized by George Deacon several decades previously. Doctor Enrique Deutz, a German physician, was allegedly the first to use homeopathic therapies in Lima after the School of Medicine granted him permission to practice medicine in the country. In 1863, government officials assigned him to lead a smallpox vaccination campaign in the Amazonian province of Loreto, northeast Peru, where he became the principal doctor. In Iquitos, Deutz came into contact with several Brazilian homeopaths, and due to "disappointments that he suffered with allopathic medicine," he became a homeopathic practitioner (Deacon, 1887a, p.148-149). We do not know how Deutz's practice changed after he embraced homeopathy, but official records indicate that upon returning to Lima, he began the city's first homeopathic practice, facing no opposition thanks to his official credentials from the School of Medicine (Diario..., 1888b, p.712).

Homeopathy reached Peru in the 1880s with the American homeopath George Deacon. Personal information on George (Jorge) E. Deacon is scarce, but records show that he was born in Paita (Peru) and had American citizenship. In the 1870s, Deacon moved to Ohio, where he earned a degree in homeopathy at Pulte Medical College in 1877, at the age of 22. Until his last days, he fought for the dissemination and acceptance of homeopathy in Peru. ${ }^{2}$ Upon graduating from Pulte, Deacon moved to Lima and began his own homeopathy practice, placing a nameplate outside his door and taking out newspaper ads as local doctors customarily did. In the early 1880s, Deacon befriended Dr. Enrique Deutz and soon became a medical consultant, taking responsibility for the care of all referred patients for several important organizations, including the Company of Life Insurance, a British corporation with capital of over five hundred thousand pounds (Deacon, 1887a; Anuncios, 1887). After some years practicing in the country, Deacon decided to publish a journal in order to expand knowledge of homeopathy. In August 1888, La Crónica Médica, the most important medical publication in Peru at the time, announced the publication of La Homeopatía, whose goal was "to disseminate Hahnemann's doctrine in the country" (Crónica, 1884, p.271). The number of printed copies and subscribers is unknown, but the magazine developed exchanges with important medical journals in Lima. Ironically, one of these was La Crónica Médica, a journal that represented the discourse of allopaths (or "regular" doctors) and included articles criticizing homeopaths, especially George Deacon (Deacon, 1887c). ${ }^{3}$ The precise number of homeopaths practicing in Peru during the nineteenth century is uncertain, and in documents from the School of Medicine and debates in Congress it is only possible to identify the name of George Deacon.

The School of Medicine rapidly responded to the increasing visibility and popularity of homeopathy, asking the health authorities in the municipality of Lima to prohibit Deacon from practicing medicine in the country. During the mid-nineteenth century, the School of Medicine of Lima, also known as San Fernando, become an exceptional institution in Latin America. The only medical training facility in Peru, a status it held until 1961, it had immense power, being responsible for multiple areas of public health in the absence of a ministry of health, which was only created in 1935 . The school not only granted professional academic degrees, but also oversaw public health, authorized foreign doctors to practice medicine in Peru, and monitored the opening and regulation of pharmacies until the early twentieth century. Clearly, the dean and the doctors under its auspices exercised great 
power and influence upon the state. Using this influence, the School of Medicine devoted tremendous energy to prosecuting non-licensed healers, especially Chinese herbalists, and to banning homeopathic medicine. ${ }^{4}$ As can be seen in the discussions inside the School of Medicine, doctors deemed the medical therapies outside the field of Western medicine mere quackery, and as such argued for their prohibition.

In 1884, the mayor of Lima had the office of Hygiene Inspection (Inspección de Higiene) shut down Deacon's practice because he did not hold a degree granted or recognized by the School of Medicine. This episode initiated a ten-year-long legal battle in which Deacon defended the freedom of practice of a different model of medical treatment, as well as patients' freedom to use it. The municipal resolution was passed in response to several reports presented by Dr. Manuel Odriozola, the dean of the School of Medicine, and Dr. Darío Torres, the Inspector of Hygiene in Lima. Both authorities pointed out that, according to article 132 of the Education Law, Deacon should have taken the School of Medicine examinations before practicing any medical therapy in the country. Deacon counter-argued that this legislation was fair and prudent, but applicable only to people who practiced under the allopathic system. He explained that the legislation could not include homeopathic medicine because when political authorities approved it in 1856, the practice was unknown in the country. Finally, he stated that allopathic and homeopathic medicine were distinct healing systems, and therefore the School of Medicine of Lima did not have the authority to assess his professional knowledge and aptitude (Expediente, 1884). In this legal process, the complainant was Lima's inspector general of Hygiene, whose report followed the School of Medicine's suggestions, recommending the prohibition of Deacon's practice. Finally, in October 1884, the mayor of Lima, Don Luis Roca y Boloña, decreed that Deacon had no right to practice his profession unless he sat the examinations required by the School of Medicine of Lima (Expediente, 1884, f.2).

As a result, the municipality of Lima informed Deacon that he had to remove the plaque outside his house and cease placing advertisements in the press. In addition, the Office of Statistics refused to receive death certificates from Dr. Deacon. Meanwhile, he continued practicing in Lima, for which infringement the mayor ordered the chief of Police to charge a ten-peso fine (Expediente, 1884, f.2). A year later, in 1885, Deacon published a text encouraging the Legislative Assembly to pass a law to protect homeopathic practitioners, who, in his words, embodied the progress of science (Deacon, 1885). Several months later, Deacon obtained his first legal victory, when Prosecutor Cárdenas, ruled that homeopathic medicine did not pose a risk to "moral and public security" and that everyone had the right to freely choose their medicinal system. Cárdenas concluded that Deacon only had to pay for his commercial license and then he could practice in the country (Dictamen..., 1891). With this favorable legal opinion, Deacon once again filed for exemption from the School of Medicine's examination. This time, his request, which had been rejected by the municipality of Lima, the School of Medicine, and the judicial branch, found itself before a new "judge:" the national Congress. In 1886, the Education Commission of the Ministry of Justice decided that the case was beyond their jurisdiction and asked Deacon to submit his request to Congress, the only institution that could grant the exemption. In 1887, Prosecutor Bueno issued a new ruling: there was no reason to make an exception 
for Deacon, but he had the right to bring the discussion to the legislative power; which moved the discussion to a new arena, the subject of the next section (Dictamen..., 1891).

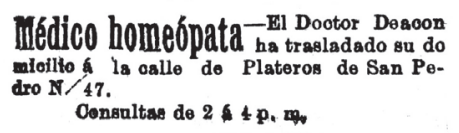

Figure 1: Advertisement (El Comercio, 20 Oct. 1888)

In the meantime, Congress defined the legal status of homeopathy in the country (18841892), and Deacon employed two strategies to overcome the obstacles imposed by San Fernando against the practice and advertising of his work: the diffusion of homeopathic ideas in spaces not controlled or influenced by the School of Medicine through the publication of the newspaper La Homeopatía and the support of important members of Congress and the judicial system. Indeed, homeopaths around the world were seeking legal recognition for their teachings and practices independently from allopathic medicine. To do this, they used diverse strategies, the most important being the creation of associations and the publication of specialized journals. During the second half on the nineteenth century in Latin America, various associations emerged, such as the Hahnemannian Society of Argentina (Sociedad Hahnemanniana Argentina), in 1869, the Mexican Homeopathic Society (Sociedad Homeopática Mexicana), in 1861, and the Fluminense Hahnemannian Institute (Instituto Hahnemanniano Fluminense), in Brazil in 1878 (Luz, 2013, p.88-89; González, 1999, p.46). While Peru lacked an association, the newspaper La Homeopatía allowed Deacon to promote the circulation of homeopathic ideas in the country.

Deacon (1887a, p.148-149) relied especially on his newspaper to defend homeopathy and to share information about its practice worldwide. In an editorial of September 1887, Deacon stated that because allopathic doctors could not stop the conversion of physicians to homeopathy, these "ignoble enemies" decided to spread false claims about it. According to Deacon, local physicians deceived and scared patients by saying that the homeopathic medicinal products, small spherical pills of compressed sugar called "globules," were poisonous. ${ }^{5}$ Paradoxically, these same doctors mocked these products, suggesting they were no more than placebos (Deacon, 1887b). Deacon claimed that reckless allopathic treatments were the real threat to the health of patients.

Like many others disciples of Hahnemann, George Deacon lashed out against physicians for their remedies and treatments. He argued that medical instruments were a form of "modern medical vampirism that will horrify our descendants," referring to the widespread use by allopathic doctors at this time of needles, vesicants, and leeches (Deacon, 1887b, p.113). He also pointed out that allopathic treatments had higher mortality rates than homeopathic ones. Deacon used cholera, a disease then common in Chile and Peru, to exemplify that "the mortality rate of those treated allopathically was $50 \%$, while those treated homeopathically was $9 \%$." These data were provided by the ambassador of Bolivia to the United States, Casimiro Corral, who had studied cholera "with the best doctors in the US" (Deacon, 1887b, p.113). While these numbers may be exaggerated, the idea that allopathic treatments resulted in higher mortality rates coincides with information from 
American homeopaths and life insurance companies. For instance, in 1870, the Albany Life Insurance Company of New York gave a ten percent discount to those members who used homeopathy. According to its own statistics, 4.17 out of every 100 people died after receiving homeopathic treatment, while 13.53 died under allopathic methods. For obvious reasons, regular medical doctors ignored these statistics (Haller, 2005, p.115).

To bolster the reputation of homeopathy, Deacon emphasized news of its use and practice in the "civilized" countries of Europe and North America. He even discussed homeopathy in Chile, which had defeated Peru in a recent war (1879-1883). Perhaps Deacon used this to encourage local readers to spread homeopathy by acknowledging that the rival nation had already embraced it. In 1887, La Homeopatía carried the news that half of the Chilean population cured themselves using homeopathy. This statistic was certainly exaggerated, as numbers did not reach these heights even in the United States, where homeopathy received both public and private sponsorship (El cólera, 1887, p.117; Briones, 2010, p.4). For example, the Homeopathic Hospital of Wards Island, New York, received over thirty thousand dollars in 1887. European homeopathy was highlighted as well. The newspaper's advertisement section recommended courses provided at the Homeopathic Institute (Instituto Homeopático) located in Madrid and directed by Tomás Pellicer.

The second strategy Deacon used was to obtain support of important members of Congress and the judicial system. Through the circulation of his newspaper, Deacon built networks with important members of the regional and Limeño elite, including congressmen and judges, who offered their support for his practice. In 1886, two years after his prohibition by the School of Medicine, an editorial in La Crónica Médica reported that Deacon still insisted on healing people (El ejercicio..., 1886, p.121). Unlike the previous case, this time he counted on the support of an influential judge. In 1886, Prosecutor Cárdenas wrote a report defending Deacon's right to practice, basing his defense on the freedom of industry and the freedom of patients to seek healing from whomever they wish, which was a very liberal discourse for its day (Dictamen..., 1891). As I will demonstrate, the arguments of Mr. Cárdenas and other supporters played a pivotal role in the Congress's discussion of Deacon's case.

\section{Seeking an impartial judge: homeopathy in Congress}

The San Fernandinos understood the exception given to Deacon in 1887 as the first step in the recognition of homeopathy as a different branch of medicine. This would lead to recognizing its autonomy from allopathy and therefore from the jurisdiction of the school. For this reason, the medical guild categorically refused to approve his practice without first sitting its examination. The concept of homeopathy as an independent science from allopathy gained momentum in 1888, when both chambers of Congress debated a bill to legislate medical practice (Diario..., 1888a, p.281-294; Diario..., 1888b, p.697-713). The speaker of the Chamber of Deputies notified his counterpart in the Senate that a bill drafted by the School of Medicine to increase its powers in public health had been approved, with some modifications. The most controversial change was undoubtedly the inclusion of a new article: "the practice of homeopathy will be governed by a special law." The Senate devoted two long and contentious sessions to discussing the special status of homeopathy 
in the country. Finally, by a vote of 26 to 9 , they rejected the proposed article. Dr. Deacon doggedly continued to defend homeopathy in the following years.

Supporters of homeopathy in Congress responded to arguments contending that the debate should not be about the efficacy of homeopathy, but crucially about securing freedom and tolerance of science. Several congressmen agreed that the disciples of Hahnemann did not infringe the moral order or the preservation of public health and that, from a strictly constitutional interpretation of the law, there was no reason to prohibit their profession. Yet if they did not accept the regulation of homeopathy by a special law, the School of Medicine would retain its monopoly over public health, a deeply "anti-liberal" idea for politicians (Diario..., 1888a, p.284). For their part, the San Fernandinos stated how "offended [they were] by this assimilation," having "protested for this epithet given to the fine and noble medical profession, a priesthood that need qualities to practice it" (El ejercicio..., 1886, p.122). Consequently, the concept of modernity played an important role in the debates about health and medicine, which looked toward "civilized" (European) countries for inspiration to organize the nation's public health (Hernández, 2018). Congress therefore extrapolated allopathy and homeopathy beyond their practitioners, framing them as part of the enduring debate between liberals and conservatives. Not surprisingly, Western medicine was associated with conservative and Catholic traditions ("priesthood"), while homeopathy reflected the triumph of modernity and the circulation and adoption of scientific knowledge from developed countries, such as the United States. ${ }^{6}$

Many supporters of a special status for homeopathy believed that guaranteeing professional freedom would attract more white immigrants to the country. One of the primary ideals of positivism was that American and European immigration would inevitably lead to progress and modernization through racial and cultural betterment (Fonseca, 2002, p.83). Positivist intellectuals and politicians were willing to expand civil liberties, such as religious freedom, to attract immigrants (Armas, 1998). From this perspective, limiting the freedom of homeopathy could scare off possible European or American immigrants. As historian Juan Fonseca argues, most of the secular policies initiated by nineteenthcentury liberals were intended to attract possible Anglo immigrants, and did not show any true enthusiasm for religious pluralism (Fonseca, 2002). Similarly, in the case of medicine, a significant number of representatives were not particularly interested in expanding medical pluralism by allowing the practice of homeopathy; they did, however, see its potential for attracting desirable immigrants. These commentators believed that imposing moral conditions would discourage potential immigrants from coming to Peru (Diario..., 1892, p.643).

Defenders of homeopathy defied the objectivity of the School of Medicine of Lima, and were firmly convinced that Congress was the only entity with legitimacy to decide their case. While doctors failed to convince Congress that there was only one true science, their animated exchange of opinions helped to lay bare the contrast between the San Fernando medical model and homeopathy. The School of Medicine could not, therefore, objectively regulate a different healing system (Diario..., 1888b, p.709). In this same line of reasoning, George Deacon showed that homeopathic and allopathic doctors were also rivals in other parts of the world. Moreover, it was no secret that Deacon had 
personal enemies in the School of Medicine, including some of its principal professors and the physician in charge of examinations for foreign doctors. These arguments about the School of Medicine's lack of objectivity strengthened over the years of the debate.

Professional doctors argued repeatedly, both in medical journals and in Congress, that homeopathy was not a branch of medicine, but a therapeutic system not so different from allopathy, with a key distinction in the preparation and application of medicines (Gall, 1884, p.205). Supporters of the School of Medicine's role as the public health authority argued it was perfectly qualified to assess homeopaths: no matter what healing method practitioners employed, the human body did not change. Both homeopaths and allopaths had to demonstrate knowledge of anatomy, physiology (the functions of the body), and pathology (diagnosing diseases) (Torres, 1884, p.286). Before concluding the debate in the upper house, Senator Velez protested "in name of the all the professors of the School of Medicine, and myself, against the ungenerous feelings that Mr. Arias [supporter of homeopathy] assumes these members have." In turn, Arias reaffirmed his deepest respect for the professionalism of doctors graduated from the School of Medicine. Because of the San Fernandinos' integrity and conviction that their school professed the truth, he continued, they could never admit the validity of a conflicting vision on medicine (Diario..., 1888b, p.712).

Supporters of George Deacon argued that in the midst of a shortage of medical practitioners, the School of Medicine should be more flexible, especially towards foreign doctors with a medical degree. As Deacon argued, statistics on the birth and mortality rates in Lima showed that two thirds of the population in 1885 perished without medical assistance (Deacon, 1885). This social and medical problem was even worse in rural towns and villages, where few doctors were available and patients lacked the means to pay for their services. According to Prosecutor Cárdenas, passing a law that limited the number of practitioners with such a scarcity of doctors would be a despotic mockery to the country (Dictamen, 1891). For several representatives, it was incomprehensible to reject George Deacon's medical degree from a foreign university when the country needed more doctors willing to provide free or low-cost medical services for its poorest citizens. To some representatives, a degree from a university in the United States was sufficient evidence of professional qualification to practice medicine in the country.

Professional doctors formed two groups in response to homeopathy. A moderate faction argued that they had never opposed homeopaths, as long as they received a degree from the School of Medicine. This was the position, for instance, of La Crónica Médica and Senator Bambarén (El ejercicio..., 1886). However, a more radical faction antagonized the debate by declaring homeopathic doctrines to be false. To this group, homeopathy was contrary to the progress of modern medicine. For instance, Dr. Romero argued that patients using homeopathy were only "cured" under the influence of suggestion, or the placebo effect. He added that the doctrinal basis of this system - the idea of a new medication, medical knowledge, and therapeutics - had been acceptable during the eighteenth century, but that "these principles are today unfounded" (Diario..., 1888b, p.701). The congressional debates entered a loop as supporters of homeopathy felt they had to defend the therapy from these attacks. 
In 1892, Deacon presented his case once again, this time before the Senate, asking to be exempted from the San Fernando examination and invoking scientific freedom. After eight years of discussions, the San Fernandinos were frustrated with Congress's role in perpetuating the debate: "And it's even more surprising that the support comes from people who, in light of their social position, should be faithful guardians of the law... whose strict enforcement will always be the guarantee of peace, stability, and progress" (Editorial, 1892). Before debating the issue, the president of the Senate requested a report from the School of Medicine. Written by Dr. Armando Vélez, M. Barros, and M. Artola, it categorically rejected the petition, quoting the law passed in 1888 under which nobody was permitted to practice medicine in the country without graduating from the School of Medicine or otherwise fulfilling its requirements (Diario..., 1892, p.631-633). Despite this report, the majority of the Senate Education Commission favored Deacon's request. The Commission then proposed that the government grant practitioners with "special diplomas to treat a specific group of diseases, as well as to cure using homeopathy" (Diario..., 1892, p.636).

Physicians criticized their colleagues for even considering a proposal that clearly violated the law, while supporters argued that there was a clear difference between "the violation of and exception from a law" (Diario..., 1892, p.645). Nevertheless, professional doctors mainly criticized both Congress and the government for getting involved in issues that they considered to be outside their jurisdiction. Doctors who trained at the School of Medicine defended their monopoly over medical knowledge, arguing that only they were qualified to deliberate on topics regarding medical issues. In the Senate debates of 1892, Dr. Bambarén argued that Deacon's request was a scientific issue, and because neither the Education Commission nor Congress was a scientific body, they could not resolve the case. Bambarén believed that their congress colleagues were ignorant and held erroneous ideas about homeopathy. For this reason, congressional doctors as Bambarén provided lectures about the scientific bases of homeopathy and allopathy (Diario..., 1892, p.637). Finally, in 1895, both chambers ruled to allow Deacon to practice homeopathy in the country, via a legal resolution issued on October 27, 1897 (Perú, 1897).

During the debates, several members of Congress not only demonstrated knowledge of the most important features of this therapeutic system, but even claimed to have been treated by Deacon himself (Diario..., 1892, p.641). Mr. Mujica stated that "there has been unjustifiable malice against this gentleman [Deacon], who with work and persistence became a homeopath, living honestly, curing several people. Maybe some people who have been cured by him are here in the Senate" (p.641). However, Dr. Bambarén dismissed Congressman Mujica's statement, pointing out his close personal ties with Deacon: "Mr. Deacon is his political nephew, and for this reason he is committed to supporting his claim" (p.641). In 1895, after several years discussing Deacon's case, Congress finally granted him authorization to practice medicine in the country without taking the exams required by the School of Medicine (Perú, 1897). In December 1895, in a letter to Thomas M. Steward, one of the first faculty members of Pulte Medical College, Deacon (1896, p.70) informed his colleague of the triumph of homeopathy in the Peruvian Congress: "only fifteen voters were against homeopathy in both houses out of hundred and fifty members of the Congress." 
The letter demonstrates that Deacon was integrated into political networks of patronage. In this document, Deacon shared the credit for this achievement with three Congressmen: Rodrigo Herrera, Senator M.A. Berujano, and Agustín Tovar, "who with their eloquence and great learning achieved victory" (Deacon, 1896, p.70). It is interesting that while homeopathy had a large number of supporters in urban circles, Herrera, Berujano, and Tovar were important members of the provincial elite, where homeopathy was not so widely disseminated. Rodrigo Herrera was a congressman for the province of Chincha (south of Lima), and Manuel A. Bejurano, was a lawyer, judge, and member of the Supreme Court who lived in the provinces of Arequipa and Puno during the 1880s and 1890s (Diario..., 1896, p.88). In the 1890s, Bejurano was elected senator for the province of Puno, in the Altiplano, and resolutely supported Deacon's request to practice his profession publicly. The American Institute of Homeopathy quoted Manuel Bejurano: "The good name of Peru demands that the doors of the country be opened to homeopathy, for it is in the interest of humanity" (Cobb, Horner, 1908, p.114).

Congressman Tovar's defense of Deacon and the practice of the homeopathy deserve special mention because of his considerable political influence. As in the case of Chile, Mexico, and Argentina, where homeopaths received support from important political figures, Tovar's advocacy tipped the balance in favor of Deacon (Garcia, 1885; Hernández, 2017). ${ }^{7}$ By 1890, Tovar was an active member of the Civil Party and in the next years held top ministerial positions. Deacon was undoubtedly a member of the country's elite class, and came to be a symbol of the modernization that the country needed. Archival records suggest that he practiced medicine in Peru at least until 1912, the last year his name appeared in the business directory Almanaque de El Comercio. He died of a heart attack in 1915 in Lima (Chorrillos).

Even though Deacon was the most prominent practitioner of homeopathy in Peru, his death did not indicate the disappearance of the practice. As I will demonstrate, a growing market for homeopathic products had started in the 1880s, and the arrival of new homeopaths in the early twentieth century revealed a thriving homeopathic subculture.

\section{Doctoring the family: homeopathic kits and domestic medicine}

In the 1888 congressional debate on the proposal to regulate homeopathy by special law, the representative Mr. Chávez argued that it was absurd to talk of two different schools of medicine in Peru. In his mind, there were not enough homeopaths: "There is only one, and therefore will we legislate for one inhabitant in Peru?" (Diario..., 1888a, p.851-852). Other congressmen followed the logic of the San Fernandinos, arguing that medical knowledge could only be administered in the traditional doctor-patient relationship. They believed that without Deacon's practice, the days of homeopathy would be numbered. However, they underestimated homeopathic medicine's emphasis on self-treatment. While the School of Medicine embarked on a project to outlaw the practice of homeopathy, by the late 1880s dozens of homeopathic products, mostly kits and books, had entered Lima's competitive medicinal marketplace. Thus, it is impossible to understand the relevance of homeopathy in Peru and other parts of the Americas 
without considering the importance of the sale and circulation of homeopathic products in the Peruvian and Limeño market.

Homeopathy was a revolutionary therapeutic system that broke the traditional patientdoctor relationship. Homeopathic doctors did not need to be physically present to make a diagnosis, as patients often mailed a letter describing their symptoms. Making diagnoses at a distance reduced the cost of medical consultations and increased patients' access to doctors. This model also allowed for the therapy to expand beyond the cities to rural areas, where people had less access to physicians but more access to mail. Furthermore, in many cases, the presence of a physician was completely unnecessary for the process of healing. Homeopathy allowed each patient to be their own doctor, offering home health tools to non-specialists in the form of instruction manuals and medical kits (Janik, 2014, p.131). We do not know if this free circulation and sale of homeopathic remedies affected the practice of homeopaths in Lima, but in the few writings recovered George Deacon there is no mention or criticism of the unrestricted sale of homeopathic remedies in the country. Considering his opinion on the importance of expanding homeopathy around the world, it follows that Deacon would have welcomed the expansion of the homeopathic market.

Peter Bacigalupi, an American immigrant and entrepreneur, played a central role in introducing and distributing homeopathic kits and handbooks in Peru. Known as "the shark of the west coast" for his abilities as a merchant, Bacigalupi was born in New York in 1855, first arriving in Peru in April 1878. He soon started a business for the import and sale of merchandise from the United States (Dahlinger, 2010, p.34). By the end of the nineteenth century, he was one of the richest men in Callao. He was also the editor and publisher of a weekly newspaper, El Perú Ilustrado (1887-1892), one of the four Lima newspapers in which he advertised his imported goods (p.34). In addition to the regular ads for George Deacon, El Perú Ilustrado also advertised the "miraculous" homeopathic products and manuals of Dr. Humphreys.

Books on domestic medicine employed simple language and provided instructions for preparing and consuming medicines (Janik, 2014, p.131).While during the first decades of the nineteenth century, homeopathy had targeted middle- and upper-class families who could read English, German, or French homeopathic literature, the translation of the classic works to Spanish opened up access to the monolingual public. For instance, in 1855, the Chilean Dr. Benito García Fernández reprinted Spanish translations of two of the most important homeopathy books of the day, Organon and Domestic medicine. In the prologue, he explained that both books "allowed enthusiasts to know more of the foundations of homeopathy, to cure themselves, and to provide some relief to poor people in countryside who die helpless" (García, 1855). Peru had a long tradition of books on domestic medicine. As the historian Adam Warren (2009) has noted, in Colonial Peru medical texts known as recetarios circulated amongst the population, offering detailed instructions for concocting homemade medical treatments and targeting those lacking a formal knowledge of medicine. The new homeopathic books fitted perfectly into this existing niche.

Homeopathic kits included bottles of ready-to-use remedies for specific ailments, and the accompanying manual providing step-by-step directions. In Peru, the products of Humphreys Homeopathic Medicine Co. were received favorably by the general public. 
Dr. Frederick Humphreys, the founder of the company, was born in New York in 1816 and graduated with a degree in Western medicine (Humphreys, 1904). In 1854, he published a book called Humphreys' homeopathic specifics to provide "remedies for every morbid condition which it is proper for an amateur or family to treat, and especially for all those diseases affecting suddenly [sic]" (Humphrey, 1884, p.5). The following year, he founded the Humphreys Homeopathic Medicine Co., which soon became one of the largest homeopathic medicine houses in the world, with capital of $\$ 500,000$ and branches in all the continents. Humphreys Homeopathic Medicine distributed medicines -especially his Humphreys Specifics kit - and books "for a thousand miles up the Amazon, though Paraguay, Uruguay, Peru and Chili [sic]" (Advertising, 1896). In his Manual and Mentor (issued respectively in 1855 and 1869), Humphreys explained the healing system of his Specifics (Humphreys, 1898). By the 1890s, the company had translated the manuals into dozens of languages, distributed 15 million copies, and broadcasted their content on radio programs throughout the world.

Humphreys Homeopathic Medicine Co. sold Spanish and English versions of the Manual in Peru as early as 1890, teaching Peruvians how to administer healing remedies prepared by a "skillful physician." The cures improved people's health through "less sickness, better health, better growth, longer and vigorous lives" (Humphreys, 1884, p.7). As of 1888, El Perú Ilustrado regularly carried advertisements for homeopathic products, as well as articles explaining how they worked. People who wanted to acquire products from Humphreys $\&$ Co. had to send a request by post to New York by July 1888. The company would then send the product, covering the cost of shipping, charging the same price around the world as they did in the United States. It seems that Bacigalupi realized the enormous business potential of Humphreys \& Co., setting up a commercial relationship with the company in July 1888. As a merchant, Bacigalupi admired the medical empire built by Frederick Humphreys, who, "with rare and valuable judgment, has made real the Yankee proverb 'the right man in the right place,' which is the secret of his successful company" (El doctor, 1888). At Bacigalupi's store in the heart of Lima's commercial district, people could buy Humphreys pamphlets and products. On December 29, 1888, El Perú Ilustrado warned that, due to high demand, the homeopathic kits would "sell out very soon."

As with many other products that Bacigalupi imported from the United States - i.e. typewriters, telephones, and Kodak cameras - homeopathic kits represented the modernity that Peruvian consumers craved: "they are as needed as railways, telegraphs, and sewing machines" (Anuncios, 1888). In Perú Ilustrado, Bacigalupi began to include reviews and more extensive news of the Humphreys Specifics, which "have made millions of wonderful cures" (Anuncios, 1888). Following the commercial success of Humphreys \& Co., other entrepreneurs soon began selling homeopathic remedies in Lima. In 1902, Botica Inglesa, the oldest pharmacy in Lima and supplier of many pharmacists and drugstores in the country, announced in El Almanaque de El Comercio the sale of "a great variety of homeopathic remedies," including the "Kits of Dr. Willmar Schwabe from Leipzig" (Anuncios, 1902).

As a consequence of this new wave of remedies, the Ministry of Industry and Trade and the School of Medicine of Lima began to receive more patent applications for homeopathic products. For instance, in 1921 the English company J.S. Fry and Sons Limited registered 
one of its products in Peru. Fry's Homeopathic Cocoa was "strongly recommended by Homeopathic Practitioners as a substitute for Tea and Coffee as not interfering with the actions of their remedies" (Perú, 1931). The Ministry granted it patent protection for ten years. In 1932 the company requested the renewal of the patent (Perú, 1931).

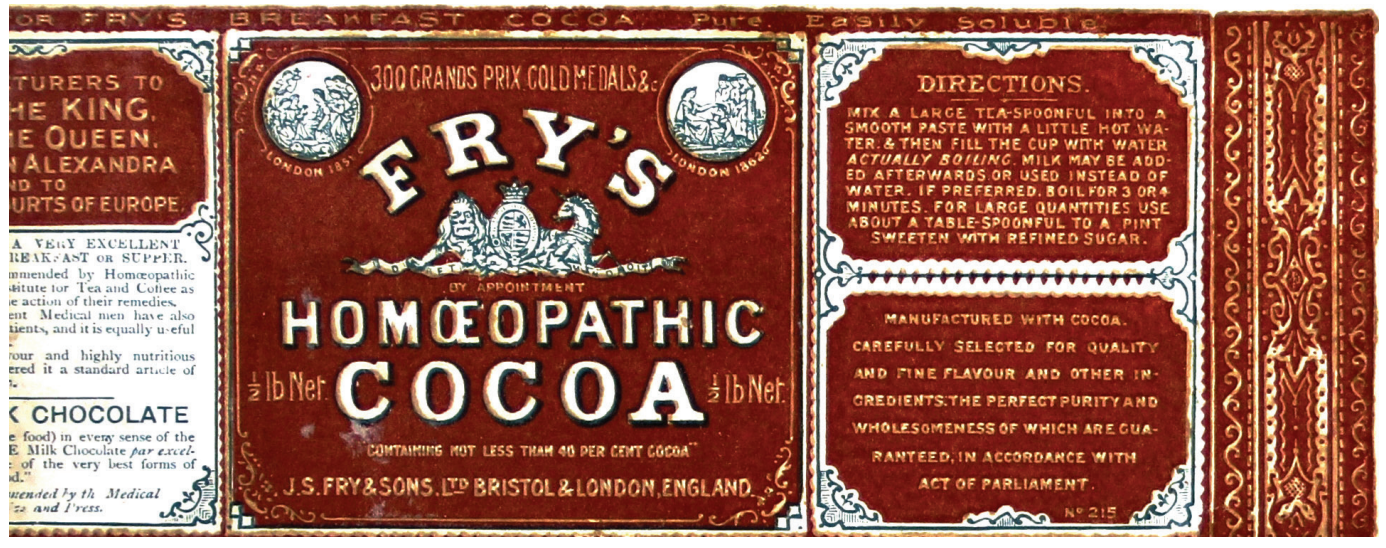

Figure 2: Fry's Homeopathic Cocoa (Perú, 1931)

It is interesting to note the complete absence of efforts on the part of the School of Medicine to block the sale of homeopathic products in legally operating pharmacies and by mail order. While the minutes of its meetings and other documents often reported on denouncements of the illegal practice of medicine, the fight against homeopathy focused on the figure of Deacon, and as a result homeopathic texts and medicines were completely ignored. The main goal of the School of Medicine was to eliminate practitioners without a medical degree from the medicinal market. This could explain why its members were so concerned with policing the practitioners of homeopathy, but not at all with the dissemination of homeopathic products. Similar to the case of the United States, the School of Medicine did not raise any objections to homeopathic products, considering them inoffensive. As James C. Whorton (2004, p.67) notes, from the allopathic viewpoint, the kits were the homeopaths' Trojan horse, a harmless-looking little box with medicines.

In 1904, the commercial firm Chirgwin Bros. \& Co. asked the San Fernando Commission of Pharmacy to analyze a series of specifics - remedies for specific diseases - for their legal sale in the country. Just as it did for other pharmaceutical products that applied for approval for marketing in Peru, the Commission of Pharmacy did the necessary studies, finding that they contained a small amount of active agents, similar to the Dr. Humphreys specifics, and therefore declaring them harmless and approved for marketing in the country. Consequently, in the following months the homeopathic specifics started being sold in the country's pharmacies (FML, 29 Apr. 1866).

While the remedies were chemically harmless, countless people benefited from doctoring themselves around the world, subsequently threatening the practices of professional doctors. As advertisements indicated, homeopathy allowed "a saving for families that could preserve health without spending on visiting doctors" (Anuncios, 1888). However, the greatest damage made by homeopathy was symbolic. During the second half of the nineteenth 
century, licensed doctors succeeded in transforming medicine into a prestigious profession, aligning themselves with the state in the modernization of the country. Doctors became part of the Peruvian elite and preserved their prestige by requiring medical practitioners to be trained in the official School of Medicine. The San Fernando doctors simultaneously battled with unlicensed practitioners and the deep-rooted idea that medical degrees were less important than a successful cure. Homeopathy put medical knowledge that had previously been the exclusive domain of some within the reach of all literate and moderately wealthy patients.

\section{Final considerations}

The homeopathic practice of Deacon in Lima reveals some relevant aspects highlighted through this article. First is the enduring presence of homeopathy in Peru, despite its marginal position compared to other countries like Mexico or Brazil. Homeopathy, and particularly the presence of George Deacon in the medicinal market, was a disruptive force that caused significant damage to the status of professional medicine, putting in question the monopoly of allopathy and the School of Medicine's agenda. George Deacon's request to practice homeopathy without the approval of the School of Medicine of Lima, bolstered by his degree from an American university, generated heated debate between allopathic doctors in San Fernando and others members of Peruvian society who supported homeopathic treatments.

Secondly, the contradictory attitude of the School of Medicine in persecuting the practice of homeopathy while ignoring the sale of homeopathic medicines demonstrates an ambivalent attitude to professional doctors to allow or prohibit others medical knowledge. The anti-quack campaigns targeted practitioners perceived as "real competition" to licensed doctors, an unstable and changing category at the time. In the last decades of the nineteenth century, professional doctors targeted pharmacists, Chinese herbalists, homeopaths, and others, as the main enemies of public health. In contrast, the doctors of the School of Medicine felt the presence of indigenous healers or natural products did not undermine their monopoly of public health. During the period analyzed, the discussion carried out in the School of Medicine against unlicensed practitioners gave precedence to medical degrees over any concept of race or nationality. Thus, they called out the practice of nonprofessional practitioners, regardless of whether they were Americans, Chinese, or Peruvians.

Finally, homeopathy has been completely ignored in the history of medicine in Peru. Although there are limitations imposed by the very small number of historical sources available, this work aims to be the first to understand the role of homeopathy in the country. Many questions still remain unanswered. For example: why did the School of Medicine persecute some healing practices like homeopathy so strongly, while ignoring others, such as the use of homemade remedies (including homeopathic products)? Was Deacon alone or were there other homeopaths in Peru in the nineteenth century? Who were they and who were their patients? Was being foreign decisive in Deacon's rejection by the School of Medicine? There is still much to be studied in the complex relationship between Peruvian doctors and non-professional medical practitioners, both domestic and foreign. 


\section{ACKNOWLEDGEMENTS}

I would like to thank the participants of the University of California Davis Latin American History Workshop, who provided me with valuable comments on a previous version of this paper. I especially thank the anonymous reviewers for their insightful comments, and José Ragas, Amie Campos, and Kenia Munguia for their editorial suggestions. I thank Stephen J. Greenberg, Coordinator of Public Services of the National Library of Medicine (Bethesda, USA) for his generosity in sending me in digital format the only two issues available of La Homeopatía around the world.

\section{NOTES}

${ }^{1}$ This work is based on a large number of historical sources contained in Peruvian and American libraries and archives. These include medical journals, like La Crónica Médica, debates in Congress, legislation, minutes of School of Medicine meetings, documents sent and received by the School of Medicine, parish archives, newspapers, and miscellaneous magazines, among many others. There are few historical sources that refer directly to homeopathy in Peru.

${ }^{2}$ Pulte Medical College was one of the first and most prestigious colleges of homeopathy in the United States. Doctors Beckwith and Buck founded it in 1872 with the support of Dr. Joseph H. Pulte, a wealthy German physician-turned-homeopath who built his reputation during the cholera epidemic of 1849. Dr. Pulte also published books on domestic medicine and translated from German to English the writings of Dr. Samuel Hahnemann, the founder of homeopathic medicine (Haller, 2005, p.146).

${ }^{3}$ For the difference between homeopathy and allopathy as models of treatment, see Haller $(2005$, chapter 1$)$.

${ }^{4}$ To read more about Chinese medicine in Peru, see Palma (2018), and Palma, Ragas (2018).

${ }^{5}$ Sugar globules are one form in which homeopathic remedies can be consumed. Hahnemann thought it was possible to obtain the full virtue of medicinal substances in globules of sugar of milk impregnated with a thirtieth dilution of the substance (Haller, 2005, p.31).

${ }^{6}$ For a discussion on modernity and medicine in Latin America and the effects of liberal ideology on nineteenth-century society, science, and culture, see Hernández (2018).

${ }^{7}$ Agustin Tovar was born in Arequipa in 1852, and lived most of his life in Puno, where he was an active member of the Civil Party and elected a senator in 1872. After 1900, Tovar took on important positions, such as minister of Public Works (1900-1901) and minister of War (1901). President José Pardo y Barreda appointed him minister of Government and Police (1907). Tovar was also the president of the Public Charity of Lima and the president of Congress (Rostworowski, 2009).

\section{REFERENCES}

ADVERTISING.

Advertising Humphreys' Specifics. Printers' Ink, v.16, n.13, p.3-5. 1896.

ADVERTISING.

El Comercio, 20 Oct.1888.

ANUNCIOS.

Anuncios. Almanaque de El Comercio, v.9, p.120. 1902.

\section{ANUNCIOS.}

Anuncios. El Perú Ilustrado, v.1, n.49, p.9. 1888.

ANUNCIOS.

Anuncios. La Homeopatía, v.2, n.19, p.118. 1887.

ARMAS, Fernando.

Liberales, protestantes y masones: modernidad y tolerancia religiosa: Perú, siglo XIX. Lima: Fondo Editorial PUCP; Centro de Estudios Regionales Andinos Bartolomé de las Casas. 1998.
BRIONES, Flavio.

Apuntes sobre la historia de la homeopatía en Chile durante los siglos XIX y XX. Boletín Informativo de la Sociedad Española de Homeopatía Clásica, v.28, p.3-6. 2010.

CARRILlO, Ana María.

¿Indivisibilidad o bifurcación de la ciencia?:

la institucionalización de la homeopatía en México. In: Sánchez, Gerardo; Dosil, Francisco (Org.). Continuidades y rupturas: una historia tensa de la ciencia en Mexico. Morelia: Instituto de Investigaciones Históricas de la Universidad Michoacana de San Nicolás de Hidalgo; Unam. p.277-310. 2010.

COBB, Joseph; HORNER, J. Richey. Report of the International Bureau of Homeopathy. In: American Institute of Homeopathy. Transactions of the 64th session 
of the American Institute of Homeopathy held in Kansas City. Cleveland: Publication Committee. p.114-124. 1908.

COULTER, Harris.

Divided legacy: the conflict between homoeopathy and the American Medical Association: science and ethics in American medicine, 1800-1914. Richmond: North Atlantic Books. 1982

CRÓNICA.

Crónica: la homeopatía. La Crónica Médica, v.1, n.8, p.271. 1884 .

DAHLINGER, Fred.

Peter Bacigalupi, San Francisco, California. The Carousel Organ, v.42, p.34-37. 2010.

DAS, Eswara.

History and status of homoeopathy around the world. New Delhi: B. Jain. 2005.

DEACON, George.

Correspondence. Medical Century: A Journal of Homeopathic Medicine and Surgery, v.4, n.3, p.7071. 1896.

DEACON, George.

La discusión en la Cámara de Diputados. $\mathrm{La}$ Homeopatía, v.2, n.23, p.148-149. 1887a.

DEACON, George.

La homeopatía: "impotencia de nuestros adversarios, sus imprudencias nos obligan a hablar alto y categóricamente". La Homeopatía, v.2, n.19, p.111-115. 1887b.

DEACON, George.

Crónica. La Homeopatía, v.2, n.19, p.118. 1887c.

DEACON, George.

La homeopatía ante la Soberana Asamblea

Legislativa del Perú. Lima: Imprenta del Teatro. 1885.

DIARIO....

Diario de los debates de la honorable Cámara de Senadores: Congreso Ordinario de 1896. Lima: Imprenta de El País. 1896.

DIARIO...

Diario de los debates de la honorable Cámara de Senadores: Congreso Ordinario de 1892. Lima: Imprenta de El Comercio. 1892.

DIARIO...

Diario de debates de la honorable Cámara de Diputados: Congreso Ordinario de 1888. Lima: Imprenta de El Nacional. 1888a.

DIÁRIO...

Diario de los debates de la honorable Cámara de Senadores: Congreso Ordinario de 1888. Lima: Imprenta de El Nacional. 1888b.
DICTAMEN...

Dictamen fiscal. El Peruano, v.50, n.60, p.473478. 1891.

\section{EDITORIAL.}

Editorial. El Monitor Médico, v.8, n.176, p.112113. 1892.

EL CÓLERA.

El cólera. La Homeopatía, v.2, n.19, p.117. 1887.

EL DOCTOR.

El Dr. Humphreys y sus célebres específicos. El Perú Ilustrado, v.1, n.63, p.171. 1888.

EL EJERCICIO...

El ejercicio de la homeopatía en el Perú. $L a$ Crónica Médica, v.3, n.28, p.121-123. 1886.

\section{EXPEDIENTE...}

Expediente seguido por el Dr. Jorge E. Deacon para que se resuelva que tiene derecho de ejercer su profesión de médico homeópata. Sección Higiene y Vacuna, caja 2 (1870-1884). (Archivo Histórico Municipalidad de Lima, Lima). 1884.

FML.

Facultad de Medicina de Lima. Documentos enviados y recibidos, Iquique (Archivo Histórico de la Facultad de Medicina de Lima, Lima). 29 Apr. 1866.

FONSECA, Juan.

Misioneros y civilizadores: protestantismo y modernización en el Perú, 1915-1930. Lima: Fondo Editorial PUCP. 2002.

GALL, Manuel.

La homeopatía. La Crónica Médica, v.1, n.7, p.205-206. 1884.

GARCÍA, Benito.

Tratado teórico práctico de homeopatía o sea Organon del arte de curar, por S. Hahnneman seguido de La medicina domestica por C. Hering, y precedido por un extenso prologo sobre las enfermedades mas comunes en Santiago, etc. Santiago: Imprenta Chilena. 1855.

GONZÁLEZ, Ricardo.

Curar, persuadir, gobernar: la construcción histórica de la profesión médica en Buenos Aires, 1852-1886. Madrid: CSIC. 1999.

HALLER, John.

The history of American homeopathy: the academic years, 1820-1935. New York: Pharmaceutical Products Press. 2005.

HERNÁNDEZ, Jethro. Homeopathy 'for Mexicans': medical popularisation, commercial endeavours, and patients' choice in the Mexican medical marketplace, 1853-1872. Medical History, v.61, n.4, p.568-589. 2017. 
HERNÁNDEZ, Luz María.

Carving a niche: the medical profession in Mexico, 1800-1870. Montreal: McGill-Queen's University Press. 2018.

\section{HUMPHREYS.}

Humphreys' Homeopathic Medicine Company. The Pharmaceutical Era, v.31, n.8, p.198. 1904.

HUMPHREYS, Frederic.

Humphreys' homeopathic mentor or family adviser in the use of specific homeopathic medicine. New York: Humphreys Homeopathic Medicine Company. 1898.

HUMPHREYS, Frederic.

Humphreys' manual: specific homeopathy for the administration of medicine and cure of disease. New York: Humphreys Homeopathic Medicine Company. 1884.

JANIK, Erika.

Marketplace of the marvelous: the strange origins of modern medicine. Boston: Beacon Press. 2014.

JENNER, Mark; WALLIS, Patrick.

The medicinal marketplace. In: Jenner, Mark; Wallis, Patrick (Ed.). Medicine and the market in England and its colonies, c. 1450-1850. New York: Palgrave MacMillan. p.1-23. 2007.

KAUFMAN, Martin.

Homeopathy in America: the rise and fall and persistence of a medical heresy. In: Gevitz,

Norman (Ed.). Other healers: unorthodox medicine in America. Baltimore: John Hopkins University Press. p.99-123. 1988.

LUZ, Madel.

A arte de curar versus a ciência das doenças: história social da homeopatia no Brasil. Porto Alegre: Rede Unida. 2013.

PALMA, Patricia.

Unexpected healers: Chinese medicine in the age of global migration (Lima and California,
1850-1930). História, Ciências, Saúde -

Manguinhos, v.25, n.4, p.13-31. 2018.

PALMA, Patricia; RAGAS, José.

Enclaves sanitarios: higiene, epidemias y salud en el Barrio Chino de Lima (1880-1910). Anuario Colombiano de Historia Social y de la Cultura, v.45, n.1, p.159-190. 2018.

PERÚ.

Patente Fry's Homeopathic Cocoa. Ministerio de Industria y Comercio. Serie Marcas y Patentes, caja 8, legajo 7, expediente 1722 (Archivo General de la Nación, Lima). 1931.

PERÚ.

Promulgando resolución de 27 de nov. de 1895 , que dispensa al Dr. Jorge Deacon el examen exigido por el reglamento de Instrucción Pública para ejercer su profesión de medico homeópata. Archivo Digital de la Legislación del Perú. Available at: <http://www.leyes.congreso.gob.pe/ Documentos/LeyesXIX/1897084.pdf >. Access on: 12 Sep. 2019. 1897.

\section{ROSTWOROWSKI, María.}

Agustín Tovar, semblanza de mi abuelo. Lima:

Universidad Nacional Agraria La Molina. 2009.

TORRES, Darío.

Inspección de higiene: en el expediente seguido por el señor Jorge Deacon ha recaído el siguiente informe. La Crónica Médica, v.1, n.9, p.286-288. 1884 .

VIJNOVSKY, Andrés Walzer.

Historia de la homeopatía en la República Argentina. Buenos Aires: Estilos Gráficos. 2008.

WARREN, Adam.

Recetarios: sus autores y lectores en el Perú colonial. Histórica, v.33, n.1, p.11-41. 2009.

WHORTON, James.

Natural cures: the history of alternative medicine in America. Oxford: Oxford University Press. 2004.

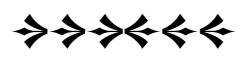

